\title{
Glycosaminoglycans affect the interaction of human plasma kallikrein with plasminogen, factor XII and inhibitors
}

A.J. Gozzo ${ }^{1}$, V.A. Nunes ${ }^{1}$, H.B. Nader ${ }^{1}$, C.P. Dietrich ${ }^{1}$, A.K. Carmona ${ }^{2}$, M.U. Sampaio ${ }^{1}$, C.A.M. Sampaio ${ }^{1}$ and M.S. Araújo ${ }^{1}$
Departamentos de ${ }^{1}$ Bioquímica and ${ }^{2}$ Biofísica, Escola Paulista de Medicina, Universidade Federal de São Paulo, São Paulo, SP, Brasil
Correspondence

M.S. Araújo

Departamento de Bioquímica

EPM, UNIFESP

Rua Três de Maio, 100, 60 andar

04044-020 São Paulo, SP

Brasil

Fax: +55-11-5572-3006

E-mail: mariana.bioq@unifesp.epm.br

Presented at SIMEC 2002

(International Symposium

on Extracellular Matrix),

Angra dos Reis, RJ, Brazil,

October 7-10, 2002.

Research supported by FAPESP, CNPq and FADA (UNIFESP-SPDM).

Received November 29, 2002 Accepted May 29, 2003

\section{Abstract}

Human plasma kallikrein, a serine proteinase, plays a key role in intrinsic blood clotting, in the kallikrein-kinin system, and in fibrinolysis. The proteolytic enzymes involved in these processes are usually controlled by specific inhibitors and may be influenced by several factors including glycosaminoglycans, as recently demonstrated by our group. The aim of the present study was to investigate the effect of glycosaminoglycans (30 to $250 \mu \mathrm{g} / \mathrm{ml}$ ) on kallikrein activity on plasminogen and factor XII and on the inhibition of kallikrein by the plasma proteins C1-inhibitor and antithrombin. Almost all available glycosaminoglycans (heparin, heparan sulfate, bovine and tuna dermatan sulfate, chondroitin 4- and 6-sulfates) reduced (1.2 to 3.0 times) the catalytic efficiency of kallikrein (in a nanomolar range) on the hydrolysis of plasminogen $(0.3$ to $1.8 \mu \mathrm{M})$ and increased (1.9 to 7.7 times) the enzyme efficiency in factor XII $(0.1$ to $10 \mu \mathrm{M})$ activation. On the other hand, heparin, heparan sulfate, and bovine and tuna dermatan sulfate improved (1.2 to 3.4 times) kallikrein inhibition by antithrombin $(1.4 \mu \mathrm{M})$, while chondroitin 4 - and 6-sulfates reduced it (1.3 times). Heparin and heparan sulfate increased (1.4 times) the enzyme inhibition by the C1-inhibitor $(150 \mathrm{nM})$.

Plasma prekallikrein is a protein that circulates in blood as the zymogen of human plasma kallikrein (huPK). Kallikrein may be involved in several physiological pathways such as activation of factor XII (1) and plasminogen by direct cleavage of the zymogen (2) or by activation of pro-urokinase (3).

The participation of huPK in physiological processes requires the existence of several controlling factors. Specific proteins have
Key words

- Glycosaminoglycans

- Human plasma kallikrein

- Plasminogen

- Factor XII

- C1-inhibitor

- Antithrombin been found to inhibit huPK activity. On the other hand, biological compounds in contact with circulating proteinases such as plasma kallikrein are thought to affect their activity $(4,5)$. The glycosaminoglycans (GAGs) are macromolecules present in blood vessels, which may interfere with kallikrein activity or inhibition $(6,7)$. Recently we demonstrated that GAGs affect the action of huPK on kininogen hydrolysis and inflammation (8). 
In the present study, we report on the influence of some GAGs on other processes in which huPK participates such as plasminogen and factor XII activation, and on huPK inactivation by the physiological inhibitors C1-inhibitor and antithrombin.

The effect of GAGs on plasminogen activation by huPK was studied by determining plasmin activity on a synthetic substrate. Briefly, $3.1 \mathrm{nM}$ huPK (8) in $50 \mathrm{mM}$ tris(hydroxymethyl)aminomethane (Tris) buffer, $\mathrm{pH} 7.4,12 \mathrm{mM} \mathrm{NaCl}$, with or without $30 \mu \mathrm{g} / \mathrm{ml}$ GAGs (9), was incubated with plasminogen $(0.3$ to $1.8 \mu \mathrm{M})$ for $2 \mathrm{~h}$ at $37^{\circ} \mathrm{C}$ as described (2). The chromogenic peptide $\mathrm{H}$-D-valyl-leucyl-lysine $p$-nitroanilide (H-DVal-Leu-Lys- $p$ Nan, $0.56 \mathrm{mM}$ ) was used to monitor plasmin activity. Plasmin generation corresponds to hydrolyzed plasminogen and its concentration was determined by comparison to the initial velocities of reaction using commercial plasmin as standard (data not shown). The catalytic parameters $\left(K_{\mathrm{M}}\right.$ and $k_{\text {cat }}$ ) calculated for plasminogen hydrolysis in the absence of any GAGs agreed with those reported by others (2). Bovine derma- tan sulfate, chondroitin 4-sulfate, chondroitin 6-sulfate, tuna dermatan sulfate and heparan sulfate reduced the catalytic efficiency of huPK from 63 to $16 \%$, while heparin was the only GAG that increased this hydrolysis (44\%), as shown in Table 1.

The contact activation system of human plasma forms a complex surface involving factor XII, prekallikrein and high molecular weight kininogen. In this complex, prekallikrein is activated to kallikrein, which activates factor XII. The active form of factor XII (factor XIIa) anchored to high molecular weight kininogen is able to activate more prekallikrein in an autocatalytic cycle. Since factor XII is a natural substrate for huPK, we studied the influence of GAGs on this interaction. Human plasma kallikrein $(10 \mathrm{nM})$ in $50 \mathrm{mM}$ Tris buffer, $\mathrm{pH} 7.4,12 \mathrm{mM} \mathrm{NaCl}$, $1 \mathrm{mg} / \mathrm{ml}$ bovine serum albumin (BSA), with or without $100 \mu \mathrm{g} / \mathrm{ml}$ GAGs, was incubated for $20 \mathrm{~min}$ at $37^{\circ} \mathrm{C}$ with factor XII $(0.1$ to 10 $\mu \mathrm{M})$. H-D-prolyl-phenylalanyl-arginine $p$-nitroanilide (H-D-Pro-Phe-Arg- $p$ Nan, $0.4 \mathrm{mM}$ ) with $0.2 \mu \mathrm{M}$ soybean trypsin inhibitor (SBTI), that completely inhibited kallikrein, and 10

Table 1. Effect of glycosaminoglycans (GAGs) on the hydrolysis of plasminogen and factor XIla by human plasma kallikrein (huPK).

\begin{tabular}{|c|c|c|c|c|c|c|}
\hline \multirow[t]{2}{*}{ GAGs } & \multicolumn{3}{|c|}{ Plasminogen } & \multicolumn{3}{|c|}{ Factor XIla } \\
\hline & $\begin{array}{c}k_{\text {cat }} \\
\left(10^{-4} \mathrm{~s}^{-1}\right)\end{array}$ & $\begin{array}{c}K_{\mathrm{M}} \\
(\mu \mathrm{M})\end{array}$ & $\begin{array}{c}k_{\mathrm{cat}} / K_{\mathrm{M}} \\
\left(10^{2} \mathrm{M}^{-1} \mathrm{~s}^{-1}\right)\end{array}$ & $\begin{array}{c}k_{\text {cat }} \\
\left(10^{-3} \mathrm{~s}^{-1}\right)\end{array}$ & $\begin{array}{c}K_{\mathrm{M}} \\
(\mu \mathrm{M})\end{array}$ & $\begin{array}{c}k_{\text {cat }} / K_{\mathrm{M}} \\
\left(10^{2} \mathrm{M}^{-1} \mathrm{~s}^{-1}\right)\end{array}$ \\
\hline Control & $3.35 \pm 0.01$ & $0.60 \pm 0.01$ & 5.58 & $1.00 \pm 0.05$ & $2.36 \pm 0.31$ & 4.24 \\
\hline Hep & $23.3 \pm 1.8$ & $2.90 \pm 0.34$ & 8.04 & $17.6 \pm 0.7$ & $5.38 \pm 0.29$ & 32.7 \\
\hline $\mathrm{HS}$ & $4.17 \pm 0.07$ & $0.89 \pm 0.04$ & 4.69 & $2.14 \pm 0.12$ & $2.64 \pm 0.31$ & 8.11 \\
\hline BDS & $11.1 \pm 0.5$ & $5.35 \pm 0.30$ & 2.08 & $0.76 \pm 0.03$ & $0.33 \pm 0.04$ & 23.0 \\
\hline TDS & $3.83 \pm 0.17$ & $0.91 \pm 0.09$ & 4.21 & $0.85 \pm 0.02$ & $0.35 \pm 0.03$ & 24.3 \\
\hline C4S & $11.1 \pm 0.5$ & $5.35 \pm 0.30$ & 2.08 & $0.53 \pm 0.02$ & $0.61 \pm 0.03$ & 8.69 \\
\hline C6S & $3.42 \pm 0.05$ & $1.25 \pm 0.03$ & 2.74 & $1.15 \pm 0.02$ & $0.59 \pm 0.03$ & 19.5 \\
\hline
\end{tabular}

huPK (3.1 nM) in $50 \mathrm{mM}$ Tris buffer, $\mathrm{pH} 7.4,12 \mathrm{mM} \mathrm{NaCl}$, with or without $30 \mu \mathrm{g} / \mathrm{ml} \mathrm{GAGs,} \mathrm{was} \mathrm{incubated}$ with plasminogen $(0.3$ to $1.8 \mu \mathrm{M})$ for $2 \mathrm{~h}$ at $37^{\circ} \mathrm{C}$. H-D-Val-Leu-Lys-pNan $(0.56 \mathrm{mM})$ was used to monitor plasmin activation (absorbance at $405 \mathrm{~nm}$ ). huPK (10 nM) in $50 \mathrm{mM}$ Tris buffer, pH 7.4, $12 \mathrm{mM} \mathrm{NaCl}, 1 \mathrm{mg} / \mathrm{ml}$ BSA, with or without $100 \mu \mathrm{g} / \mathrm{ml} \mathrm{GAGs}$, was incubated for $20 \mathrm{~min}$ at $37^{\circ} \mathrm{C}$ with factor XII $(0.1$ to $10 \mu \mathrm{M})$. H-DPro-Phe-Arg-pNan $(0.4 \mathrm{mM})$ with $0.2 \mu \mathrm{M} \mathrm{SBTI}$ and $10 \mu \mathrm{g} / \mathrm{ml}$ Polybrene were used to monitor factor XIla activation (absorbance at $405 \mathrm{~nm}$ ). BDS = bovine dermatan sulfate; $\mathrm{C} 4 \mathrm{~S}=$ chondroitin 4-sulfate; $\mathrm{C} 6 \mathrm{~S}=$ chondroitin 6-sulfate; Hep = heparin; HS = heparan sulfate; TDS = tuna dermatan sulfate. Data are reported as means \pm SEM. 
$\mu \mathrm{g} / \mathrm{ml}$ Polybrene that prevented continued factor XII activation, were added and the activity of formed factor XIIa was evaluated by hydrolysis of chromogenic peptide by measuring absorbance at $405 \mathrm{~nm}$ (10). The concentration of formed factor XIIa, and hence of hydrolyzed factor XII, was determined by comparison to the velocities of reaction of known concentrations of factor XIIa. The $K_{\mathrm{M}}$ and $k_{\text {cat }}$ values for the hydrolysis of factor XII by huPK in the absence of GAGs were determined to be $2.36 \mu \mathrm{M}$ and $1.00 \times 10^{-3} \mathrm{~s}^{-1}$, respectively, as shown in Table 1. Heparin, tuna dermatan sulfate, bovine dermatan sulfate, chondroitin 6-sulfate, chondroitin 4-sulfate and heparan sulfate markedly increased (1.9 to 7.7 times) the catalytic efficiency of the enzyme on factor XII activation.

In order to study the effect of GAGs on huPK inhibition, a kinetic assay was performed based on a method described previously $(6,11)$. The proteinase inhibitors $\mathrm{C} 1$ inhibitor or antithrombin (12) with or without GAGs were preincubated in $50 \mathrm{mM}$ Tris buffer, $\mathrm{pH} 8.0,150 \mathrm{mM} \mathrm{NaCl}$ at $37^{\circ} \mathrm{C}$ for 5 min. After this period, pre-warmed huPK at final concentrations of 72-86 nM was added to the reactions, and 50- $\mu 1$ aliquots were removed at various times ( 0 to $20 \mathrm{~min}$ ). Residual enzyme activity was assessed on the hydrolysis of the chromogenic substrate $\mathrm{N}$ - $\alpha$-acetyl-phenylalanyl-arginine $p$-nitroanilide (Ac-Phe-Arg- $p$ Nan, $0.7 \mathrm{mM}$ ), monitored at $405 \mathrm{~nm}$. The kinetics of huPK inhibition was studied with the inhibitors in 2- to 65-fold molar excess and each rate constant was determined twice. The straight lines obtained when natural logarithm of huPK residual activity was plotted versus time indicate a pseudo-first-order kinetic. The values of the apparent first-order rate constants $(\mathrm{k})$ were calculated from the slopes of those lines and were found to be directly proportional to the inhibitor concentrations - [I] (data not shown). The second-order rate constants (k") were calculated from the equa- tion $\mathrm{k}=\mathrm{k}$ " $\mathrm{x}[\mathrm{I}]$.

The data showed a second-order rate constant of $240 \mathrm{M}^{-1} \mathrm{~s}^{-1}$ for kallikrein inhibition by antithrombin, in agreement with a previous study (4); this rate, however, increased about 3.4-fold in the presence of heparin (Table 2). In addition, it was demonstrated that antithrombin-mediated huPK inhibition is enhanced by heparan sulfate and bovine and tuna dermatan sulfate, and is impaired by chondroitin 4- and 6-sulfates. Kallikrein inhibition by $\mathrm{C} 1$-inhibitor was slightly increased in the presence of GAGs (Table 2) according to the calculated apparent secondorder rate constants.

The relationship between increased iduronic acid and sulfate contents and the enhancement of anticoagulant and antithrombotic activities has been established $(13,14)$. The dual action of the different GAGs on huPK inactivation could be explained by analyzing their carbohydrate composition. It is known that GAGs contain iduronic acid and sulfate. Our results showed that chon-

Table 2. Second-order rate constants for the inactivation of human plasma kallikrein (huPK) by antithrombin and C1-inhibitor in the presence of glycosaminoglycans (GAGs).

\begin{tabular}{lll}
\hline & $\begin{array}{c}\text { Antithrombin } \\
\left(10^{3} \mathrm{M}^{-1} \mathrm{~s}^{-1}\right)\end{array}$ & $\begin{array}{c}\text { C1-inhibitor } \\
\left(10^{3} \mathrm{M}^{-1} \mathrm{~S}^{-1}\right)\end{array}$ \\
\hline Control & $0.240 \pm 0.004$ & $17.0 \pm 0.1$ \\
Hep & $0.810 \pm 0.054$ & $23.0 \pm 0.6$ \\
HS & $0.560 \pm 0.038$ & $22.0 \pm 1.0$ \\
BDS & $0.530 \pm 0.013$ & $20.0 \pm 0.3$ \\
TDS & $0.290 \pm 0.024$ & $19.0 \pm 0.7$ \\
C4S & $0.200 \pm 0.002$ & $18.3 \pm 0.5$ \\
C6S & $0.180 \pm 0.014$ & $18.0 \pm 0.3$
\end{tabular}

C1-inhibitor or antithrombin with or without GAGs were preincubated in $50 \mathrm{mM}$ Tris buffer, $\mathrm{pH}$ 8.0, $150 \mathrm{mM} \mathrm{NaCl}$ at $37^{\circ} \mathrm{C}$ for $5 \mathrm{~min}$. huPK (72-86 nM) was added and $50-\mu \mathrm{l}$ aliquots were removed at various times (0 to $20 \mathrm{~min}$ ). Residual enzyme activity was assessed on the hydrolysis of AcPhe-Arg-pNan (0.7 mM), monitored at $405 \mathrm{~nm}$. BDS = bovine dermatan sulfate $(100 \mu \mathrm{g} / \mathrm{ml})$; C4S = chondroitin 4-sulfate $(250 \mu \mathrm{g} / \mathrm{ml})$; C6S = chondroitin 6-sulfate $(200 \mu \mathrm{g} / \mathrm{ml})$; Hep $=$ heparin $(60$ $\mu \mathrm{g} / \mathrm{ml}) ; \mathrm{HS}=$ heparan sulfate $(70 \mu \mathrm{g} / \mathrm{ml}) ;$ TDS = tuna dermatan sulfate $(100 \mu \mathrm{g} / \mathrm{ml})$. 
droitin sulfate, which does not contain iduronic acid, has no significant action on huPK inhibition while bovine dermatan sulfate, that contains more iduronic acid than tuna dermatan sulfate, increases the inhibition. Heparin and heparan sulfate, having high sulfate content, also increase the inhibition.

The mechanism by which glycosaminoglycans interfere with huPK activity and inhibition is not understood. However, some possible mechanisms have been postulated by others $(8,15)$ : i) GAGs may bind to enzymes inducing a conformational change, leading to a more or less active form; ii) GAGs may bind to natural substrates or inhibitors, neutralizing their positive charges and interfering with their hydrolysis or inhibition.

It has been reported that some circulating proteins such as factor XI contain structural elements involved in the interactions with GAGs (16). These elements include basic amino acids that form positively charged binding sites for the negatively charged GAGs (17). Thrombin, however, comprises a more complex binding region involving charged residues that are not essentially adjacent to each other in the primary amino acid sequence, but are close together in the correctly folded protein $(18,19)$. Since huPK shares high structural homology with factor XI (20), it was not surprising to observe that consensus sequences related to heparin binding sites are present in huPK.

The physiological role of the presumed interactions between huPK, GAGs and natural substrates and inhibitors is not known. However, since some GAGs such as dermatan sulfate have no deleterious effects on the organism, they appear to be candidates for therapeutic use in processes in which kallikrein participates such as fibrinolysis and blood coagulation or in processes involving uncontrolled huPK activity.

\section{References}

1. Jackson CM \& Nemerson Y (1980). Blood coagulation. Annual Review of Biochemistry, 49: 765-811.

2. Jörg M \& Binder BR (1985). Kinetic analysis of plasminogen activation by purified plasma kallikrein. Thrombosis Research, 39: 323331.

3. Ichinose A, Fujikawa K \& Suyama $T$ (1986). The activation of prourokinase by plasma kallikrein and its inactivation by thrombin. Journal of Biological Chemistry, 261: 3486-3489.

4. Olson ST, Sheffer R \& Francis AM (1993). High molecular weight kininogen potentiates the heparin-accelerated inhibition of plasma kallikrein by antithrombin: role for antithrombin in the regulation of kallikrein. Biochemistry, 32: 12136-12147.

5. Lin Y, Pixley RA \& Colman RW (2000). Kinetic analysis of the role of zinc in the interaction of domain 5 of high-molecular weight kininogen (HK) with heparin. Biochemistry, 39: 5104-5110.

6. Wuillemin WA, Eldering $E$, Citarella $F$, de Ruig $C P$, ten Cate $H$ \& Hack CE (1996). Modulation of contact system proteases by glycosaminoglycans. Selective enhancement of the inhibition of factor Xla. Journal of Biological Chemistry, 271: 12913-12918.

7. Brunnee $T$, Reddigari SR, Shibayama $Y$, Kaplan AP \& Silverberg M (1997). Mast cell derived heparin activates the contact system: a link to kinin generation in allergic reactions. Clinical and Experimental Allergy, 27: 653-663.

8. Gozzo AJ, Nunes VA, Carmona AK et al. (2002). Glycosaminoglycans affect the action of human plasma kallikrein on kininogen hydrolysis and inflammation. International Immunopharmacology,
2: $1861-1865$

9. Nader HB, Ferreira TM, Paiva JF, Medeiros MG, Jeronimo SM, Paiva VM \& Dietrich CP (1984). Isolation and structural studies of heparan sulfates and chondroitin sulfates from three species of molluscs. Journal of Biological Chemistry, 259: 1431-1435.

10. Tankersley DL \& Finlayson JS (1984). Kinetics of activation and autoactivation of human factor XII. Biochemistry, 23: 273-279.

11. Araújo MS, Nunes VA, Gozzo AJ, Sampaio MU, Auerswald E, Ura N, Shimamoto K \& Sampaio CAM (1999). Preliminary characterization of a Kazal-type serine protease inhibitor from Caiman crocodilus yacare plasma. Immunopharmacology, 45: 179-183.

12. Takahashi HK, Nader HB \& Dietrich CP (1981). A method for rapid quantitation and preparation of antithrombin III-high-affinity heparin fractions. Analytical Biochemistry, 116: 456-461.

13. Linhardt RJ, al-Hakim A, Liu JÁ, Hoppensteadt D, Mascellani G, Bianchini P \& Fareed J (1991). Structural features of dermatan sulfates and their relationship to anticoagulant and antithrombotic activities. Biochemical Pharmacology, 42: 1609-1619.

14. Schwartz NB (1992). Carbohydrate metabolism II: special pathways. In: Devlin TM (Editor), Textbook of Biochemistry: with Clinical Correlations. 3rd edn. Wiley-Liss, New York.

15. Evans DL, Marshall CJ, Christey PB \& Carrell RW (1992). Heparin binding site, conformational change, and activation of antithrombin. Biochemistry, 31: 12629-12642.

16. Ho DH, Badellino K, Baglia FA, Sun MF, Zhao MM, Gailani D \& Walsh PN (2000). The role of high molecular weight kininogen and 
prothrombin as cofactors in the binding of factor XI A3 domain to the platelet surface. Journal of Biological Chemistry, 275: 2513925145.

17. Kjellen L \& Lindahl U (1991). Proteoglycans: structures and interactions. Annual Review of Biochemistry, 60: 443-475.

18. Gan Z, Li Y, Chen Z, Lewis S \& Shafer J (1994). Identification of basic amino acid residues in thrombin essential for heparin-cata- lyzed inactivation by antithrombin III. Journal of Biological Chemistry, 269: 1301-1305.

19. Sheehan J \& Sadler J (1994). Molecular mapping of the heparinbinding exosite of thrombin. Proceedings of the National Academy of Sciences, USA, 91: 5518-5522.

20. Asakai R, Davie EW \& Chung DW (1987). Organization of the gene for human factor XI. Biochemistry, 26: 7221-7228. 